\title{
Medieval Islamic Navigation in the Atlantic
}

\author{
David C. Nicolle \\ Nottingham University, UK
}

Medieval Islamic navigation in the Atlantic Ocean extended over greater distances than is generally realized. Most was in a region bordered by the Iberian peninsula, the north-western coast of Africa, the Canaries Islands, the Azores and Madiera, some of these islands being well known while others were little more than sailors' legends. This region of the ocean has sometimes been the so-called "Mediterranean Atlantic" as it was closely linked in technological, economic and historical terms with the Mediterranean side of the Straits of Gibraltar. Most voyages by Muslim sailors in this "Mediterranean Atlantic" were undertaken for commercial, diplomatic or military reasons though some were a result of that intellectual curiosity, which characterized the golden age of medieval Islamic civilization.

Roman vessels plied the coastal waters from the Straits of Gibraltar and the Iberian peninsula to the English Channel and British Isles. After the collapse of the western half of the Roman Empire a maritime link appears to have survived between the Iberian peninsula and the Celtic western fringes of Brittany, the British Isles and Ireland during the Visigothic period, before the Arab-Islamic conquest of alAndalus but most particularly in the $7^{\text {th }}$ century AD.' This may have survived into Arab-Islamic period since it is clear that Britain remained the main source of tin for al-Andalus well into the $9^{\text {th }}$ century $\mathrm{AD} .^{2}$ Furthermore, it is worth noting that the famous terror stories about the Atlantic, or Sea of Darkness as it was widely known in the Islamic world, all seem to stem from the Middle East. ${ }^{3}$ None seem to have originated amongst the Arabized people of Morocco or al-Andalus.

The most famous seafarers of the early medieval Atlantic were, of course, at first the Celtic Irish and after then the Scandinavian Vikings. However, in reality two peoples habitually sailed the eastern Atlantic during the early medieval centuries - the Vikings and the Muslim Andalusians. While the latter never ventured as far as the Scandinavians, they remained the Vikings' only real rivals. Furthermore, it was Viking raids, which prompted the Umayyad rulers of Cordoba (Qurtuba) to sent at least one official embassy to the far north, almost certainly to discover the source of 
this sudden outburst of naval aggression from those little-known northern parts of the world. ${ }^{4}$

The Viking threat soon became serious enough for an Umayyad naval squadron to be created specifically to patrol the Atlantic coast of al-Andalus. These patrols remained in existance from the mid- $9^{\text {th }}$ to $10^{\text {th }}$ centuries AD. The first Umayyad Andalusian naval bases had, of course, been on the Mediterreanean coast but in the mid- $10^{\text {th }}$ century additional facilities, including shipbuilding arsenals, were constructed at Ageciras (al-Jazyra al-Khadra), Silves (Shilb) and Alcacer do Sol (Qașr Abī Danis) on the Atlantic coast. The resulting Atlantic fleets then proved themselves fully capable of defeating a major Viking raid in $966 \mathrm{AD}$ and another in $971 \mathrm{AD} .^{5}$ These successes were followed by the Vizir al-Mansur's ambition combined operations assault upon the north-western Spanish city of Santiago in $997 \mathrm{AD}$.

One of the commanders of a naval patrol, which fought Viking raiders in 8S9 $\mathrm{AD}$, was named Khashkhāsh Ibn Sa'id Ibn Aswad of Pechina (Bajjana). One of the so-called "Adventurers of Lisbon" was also named Khashkhāsh and he made several expeditions far into the Atlantic before he disappeared along with his companions. ${ }^{6}$ Their voyage north proved dangerous and won little reward. Nevertheless, it probably reached Scandinavian settlements in Ireland where the "Adventurers" were said to have been told that exploration of the Atlantic had already been done by a previous generation, probably meaning by those Vikings who had reached Iceland and would soon sail to Greenland and even North America. The "Adventurers" subsequent voyages headed southward and achieved greater reward in Bilād al-Sudam, beyond the Canary Islands. It is even possible that they reached as far as the Cape Verde Islands. $^{7}$

The flourishing fishing fleets of Lisbon (al-Ushbuna) and what is now the Algarve (al-Gharb) in southern Portugal also ranged far into the Atlantic as well as venturing down the western coast of Africa in search of good fishing grounds. ${ }^{8}$ Meanwhile, the Atlantic coast of Morocco saw considerable economic expansion in the $12^{\text {th }}$ century AD and the Muwaḥhid ruler 'Alī Ibn Yūsuf even reportedly planned an abortive naval expedition to conquer the Canary Islands. In the early $13^{\text {th }}$ century $\mathrm{AD}$, a mariner named Ibn Fātima and his crew were wrecked off Ras Nu'adhibuin, much further south in what is now Mauretania. ${ }^{10}$ When taken together, these reports give a 
distinct impression that such voyages were quite normal and perhaps even commonplace. During the reign of the Marinid sultan Ya qūb alManșur (12 58-86 AD), an engineer from Seville (Ishbiliya), named Muhammad Ibn al-'Alī, established a dār al-șinā 'a or naval arsenal at Sala on the Atlantic coast of Morocco. ${ }^{11}$ Many years later the socalled "Sallee Rovers"- meaning pirates from Sala in Morocco - who raided southern England in the $16^{\text {th }}$ century $\mathrm{AD}^{12}$ included amongst their crews men of Andalusian origin. The military capabilities of western Islamic fleets had clearly not disappeared with the collapse of the Umayyad Caliphate of Cordova, and in 1340 AD a Moroccan fleet had destroyed a Castilian-Spanish fleet near Algeciras. ${ }^{13}$ This happened at a time when European observers regarded the Castilian fleet as the most powerful in Atlantic Europe.

The concept of a spherical world was widely accepted by educated people in the $13^{\text {th }}$ century Islamic world and the Algarve region remained a centre of geographical science, including the manufacture of spherical celestial globes, even after it was conquered by the Portuguese in the $13^{\text {th }}$ century. Here, the idea that Africa could be circumnavigated and that inhabited "islands" existed far out into the Atlantic similarly survived. The role of this Algarve region during the first phase of Portuguese overseas exploration in the $15^{\text {th }}$ century is well known. ${ }^{14}$ What is less well known is the fact that the Algarve seems to have played a major role in the evolution of the ArabAndalusian form of widely used Islamic trading vessels called a qarib and a gurab $b^{15}$ into the famous caravel. The latter was, of course, used by Portuguese and Spanish explorers such as Vasco da Gama, Christopher Columbus, and many others during the $15^{\text {th }}$ and $16^{\text {th }}$ centuries AD.

Given the speed with which new technology, including maritime technology, is known to have spread across the medieval Islamic world, it seems inconceivable that new naval ideas from the Indian Ocean should not have reached the Atlantic coast. The question of when knowledge of the hinged rudder, invented by the Chinese, reached the Islamic Middle East, and to what degree it may or may not have been adopted in the Arabian Gulf and Red Sea regions, has already been considered, ${ }^{16}$ but many other problems remain unsolved.

For example, the sophistication of a pre-existing Celtic naval tradition in the Atlantic is indicated by the remains of a substantial ship found off Guernsey in the Channel Islands. ${ }^{17}$ The massive way in 
which this vessel was constructed was very different from the somewhat flimsey Mediterranean naval architecture brought north by the Romans. Potentially very interesting in the context of IberianAndalusian navigation in the medieval Atlantic are certain design features which the Guernsey wreck seems to have in common with the few existing pictorial representations of western Islamic "Atlantic" ships. The most obvious is an angled keel and stempost construction. This is in clear contrast with the rounded hull form of both Roman and medieval Mediterranean vessels. The second might be a sort of cutwater where the keel and stempost join, a feature also seen in the medieval Red Sea. ${ }^{8}$ It might also be worth noting that the written sources suggest, without specifically stating, that the Andalusian Atlantic squadron was able to defeat Viking raiders in the 10th century because they carried larger crews - perhaps because the shini Arab-Islamic galley was larger. ${ }^{19}$ Perhaps they were also more strongly built.

Hulls with angled rather than rounded outlines returned to northern waters in the $13^{\text {th }}$ and $14^{\text {th }}$ centuries in the form of the famous cog, following the decline of the sleek but much smaller rounded hulls of Viking and post-Viking vessels, The reappearance of such angled hulls in the western Mediterranean during the $14^{\text {th }}$ century is usually attributed to the influence of northern $\operatorname{cog} s$ arriving via the Straits of Gibraltar. Yet, the possibility of such a hull-form having survived in the Islamic Maghrib and al-Andalus should not be entirely ignored. Unfortunately, little research has yet been done on the ships used by Muslim Andalusian and Moroccan sailors in the Atlantic. This may prove to be a fruitfull field of study and is certainly worth consideration. 


\section{Captions}

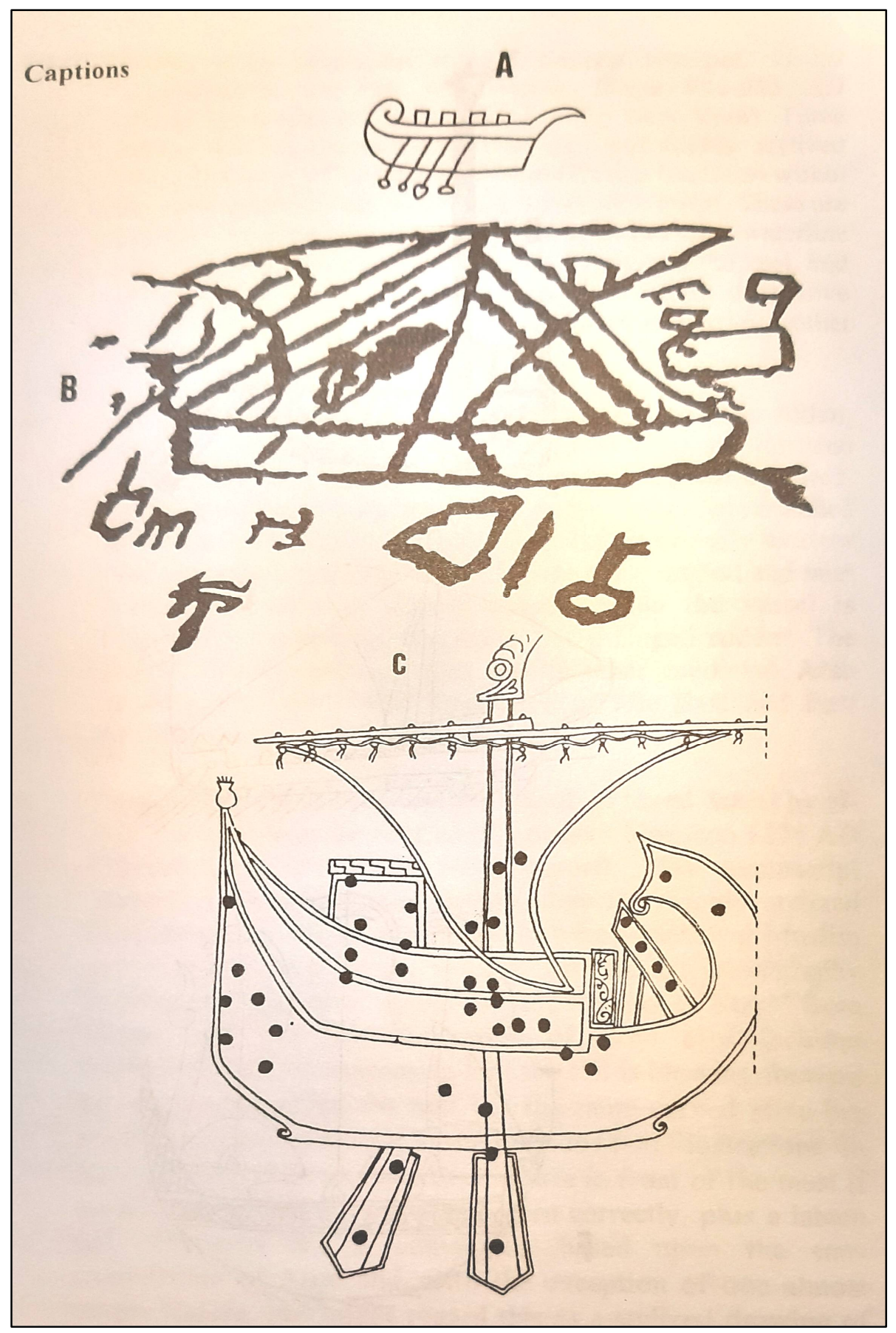




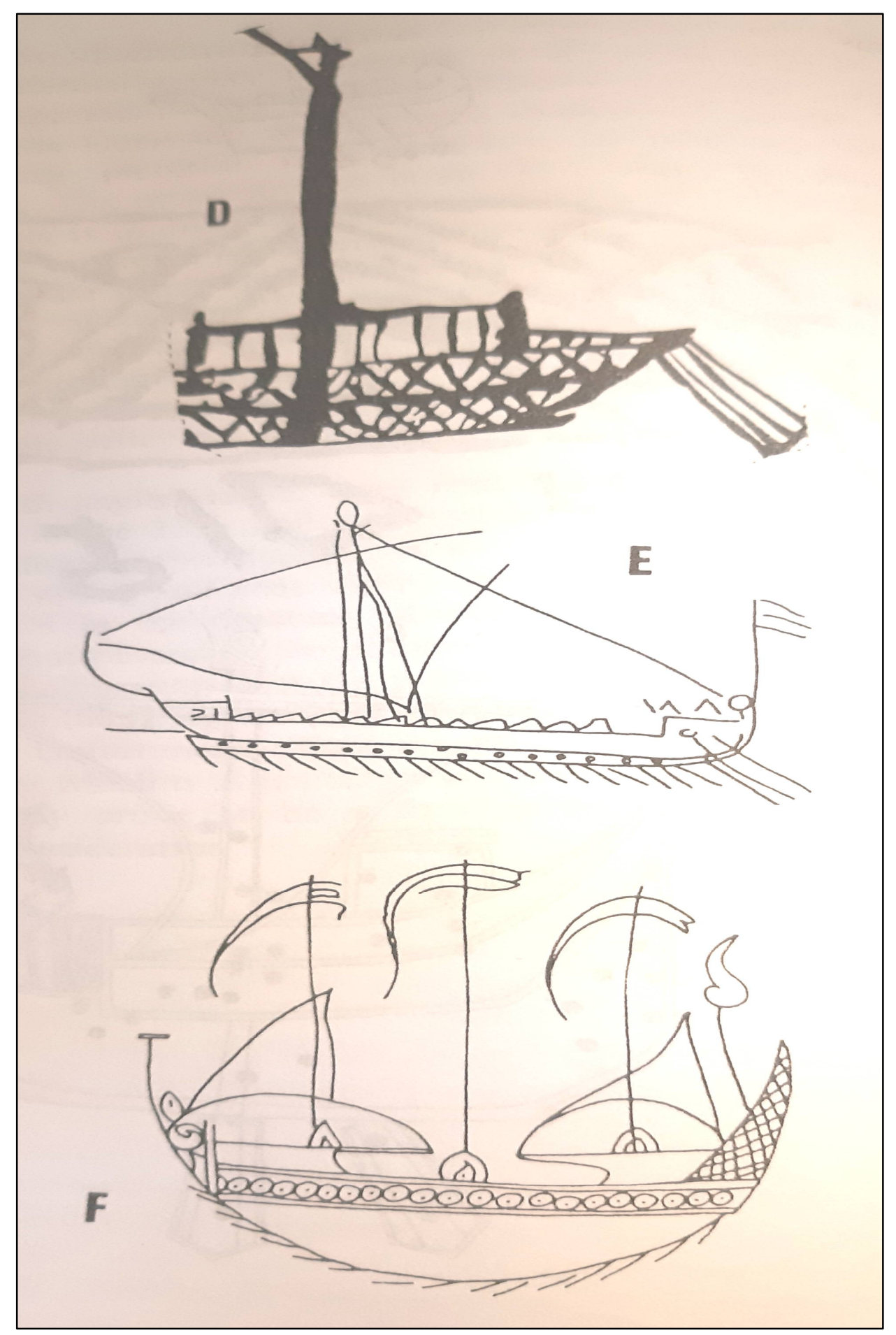

$-8-$ 
A Galley in an illustration of "The Second Trumpet," Beaus Commentaries on the Apoccalypse, Iberia 922-952 AD (Pierpont Morgan Lib., Ms. 644, f. 137r, New York). Three points need to be noted in this tiny and highly stylized drawing from a $10^{\text {th }}$ century Mozarab (Iberian Christian within the Andalusian Islamic cultural context) manuscript. These are the possible existance of a raised beak instead of a waterline ram, the straight stempost attached at an angle to the keel, and the curved stern which continues to form a high decorative poop. Similar hull forms may be shown in various other pictorial sources of Islamic origin.

B A petraglyph or rock-drawing of a sailing ship at Azru Aklan, near the western end of the Wadi Draa in southern Morocco not far from the Atlantic coast. Although it cannot be dated, the shape of the hull and the sail suggests that it was scratched on a rock in the medieval rather than ancient or early modern eras. The sail is basically triangular, the prow angled and near vertical, the stern apparently curved, while the vessel is controlled by a steering oar instead of a hinged rudder. The simple style of drawing also recalls other medieval Arab "sailor's drawings" from Egypt, the Middle East and East Africa.

C "Argo" in the Suwar al-Kawaklb (Book of Fixed Stars) by alSufi; copy made in Sabta (Ceuta), northern Morocco 1224 AD (Vatical Lib., Ms. Ross 1033, Rome). This manuscript contains a perhaps unique though obviously highly stylized illustration of a vessel of the type in which medieval Muslim sailors may have plied the western Atlantic. Its iconography is, of course, based on earlier Islamic "Books of Stars" from further east, yet this illustration of Argo also includes interesting features. Assuming that the sail is blowing forward as one would expect, the hull has the same curved stern but angled stempost as shown in the previous two illustrations. In addition there is an unusual deck-house in front of the mast if we have identified the prow and stern correctly, plus a lateen 
sail. The oars are a convention based upon the starconstellation of Argo and, with the exception of one almost unique feature, one might regard this as a stylized drawing of an ordinary early $13^{\text {th }}$ century merchant ship. The exception lies at the ends of the keel where two apparent cutwaters are shown. These could be dismissed as artistic conventions were it not for the fact that exactly the same feature is found on a crude medieval drawing from the Egyptian Red Sea port of Qusayr (figure D). Perhaps it was a feature of Islamic ships operating in tidal seas such as the Atlantic and Indian Oceans which had to be beached rather than docked, as in the tideless Mediterranean.

D Part of a simple sketch or drawing on a fragment of paper found by archaeologists in the rubbish dumps of medieval Qusayr (Old Qusayr) on the Red Sea coast of Egypt, $13^{\text {th }}-14^{\text {th }}$ centuries AD (Museum of Islamic Art, inv. 1097, Cairo). It is impossible to state with certainty whether this little drawing from the early Mamluk period shows the prow or stern of the ship. The vessel was probably single-masted, perhaps with a yard-arm to hold a lateen sail, and it seems to have a substantial midships deckhouse which extends both ahead of and behind the mast. The stem or sternpost is essentially straight with a series of ropes or perhaps two steering oars extending from it. Most interesting, in the context of this study, is a small extension or cutwater at the end of the keel. Perhaps it was to protect the keel when beaching the ship.

E This simple but better-known stratched graffito comes from Malaga on the southern coast of Spain and is generally thought to date from the $14^{\text {th }}$ or 15 th centuries (Museo Naval, Madrid). It illustrates a typical single-masted Mediterranean galley with a lateen sail, a raised boarding beak rather than a ram, probably a single bank of oars, slightly raised fore and aft castles, and steering oars rather than a hinged rudder. This latter feature would, in fact, point to a date earlier than the 14th century - perhaps considerably so. One may, however, assume that such galleys were responsible for maintaining Islamic communications between al-Andalus and Morocco. 
F Polychrome ceramic bowl from Rabat, $15^{\text {th }}$ century AD (Archaeological Museum, Rabat). The ceramics of later medieval North Africa are crude in comparison to those of Andalusia and of the Islamic Middle East. The ship on this piece is highly stylized but certain features can be identified. The vessel has three masts, two of which carry lateen sails, plus what appears to be a bank of oars though these are not connected to a possible row of oar-ports. Even the crosshatched triangular projection on the right or presumed stern recalls features seen in earlier Middle Eastern Islamic representations of ships. Perhaps such forms of ceramic were traditional and they might have no connection with contemporary shipping. On the other hand Rabat is very close to S ala, the home-port of the famous "Sallee Rovers." These North African corsairs used three-masted xebecs and ranged across much of the north Atlantic during the 16th and $17^{\text {th }}$ centuries.

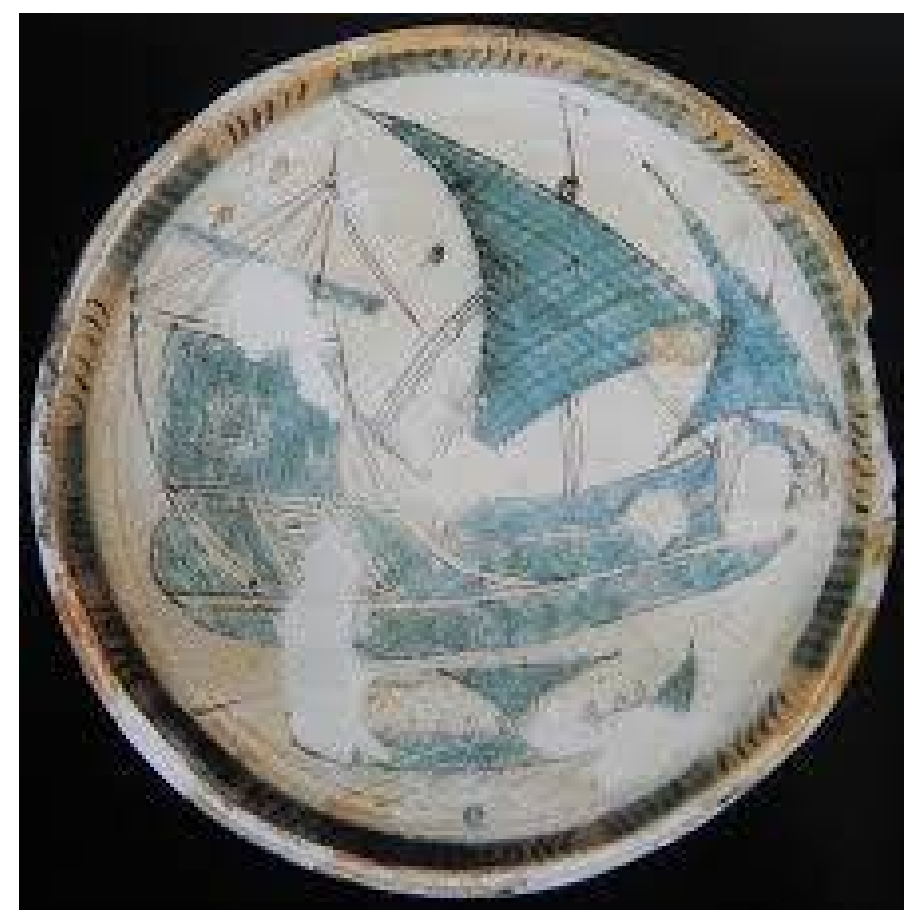

G The best preserved of two tin-glaze ceramic bowls from the church of S. Piero a Grado in Pisa, 11th century AD (Museo Nazionale di S. Matteo, Pisa). The two bowls were used as 
bacini, inserted as a form of architectural decoration into the structure of the Church. They were almost certainly made in the Balearic Islands of Spain which were then under Islamic rule and formed part of the flourishing Andalusian kingdom of Denia. The ships themselves are fully within a medieval Mediterranean tradition of lateen sailed "round ships" with high stern-castles, as illustrated in many sources from Iberia and Italy. However, these bowls are particularly important because of their date and provenance. They are considerably earlier than previously known pictures of three-masted ships and might support the idea that multi-masted vessels did not disappear from the early medieval Mediterranean following the collapse of the Roman Empire. Or perhaps they might at least have survived in those regions which became the western Islamic world. Current research into the history of Islamic technology is also strengthening the view that the Islamic world was, for many centuries, the major inovator in technological terms. ${ }^{20}$ This may also have applied to ship design and methods of construction, in which case those specifically medieval features which distinguish the medieval Mediterranean "roundship" from its two-masted Roman predecessor the corbita may have been a shared Byzantine and Islamic development or indeed a largely Islamic one.

\section{Footnotes:}

1- J. N. Hillgarth, Visigothic Spain, Byzantium and the Irish (London 1985) passim.

2- M. Lombard, Les Mélaux dans l'ancient monde du $V^{e}$ au XI siècle (Paris 1974) Map A, \& passim; J.W. Allan, Persian Metal Technology 700- 1300 AD (Oxford 1979) 2 7-28; Ibn Sa'id, cited in E, Ashtor, Les métaux précieux et la balance des payements du proche-orient à la basse époque (Paris 1971) 53-56.

3- D. M. Dunlop, "The British Isles according to Medieval Arabic Authors," Islamic Quarterly IV (1957) 11.

4- Dunlop, "The British Isles", 12-14; ibid., "Al-Bahr al-Muhit," in Encyclopedia of Islam, $2^{\text {nd }}$ edit., vol. I (Leiden 1960) 934.

5- Dunlop, "The British Isles", 12, 15 \& 19; ibid., "Al-Bahr alMuhit," 934; E. Lévi-Provençal, Histoire de l'Espagne Musulmane 
(Paris \& Leiden 1950-1967) vol I, 218-225, 310-312 \& passim, vol II, 156, 170-171 \& 180, vol. III, 93, 106-107, 111, 321, 336 \& 342; D. C. Nicolle, "Moors against Majus: The Defence of Spain and Morocco against the Vikings 844-972 AD," Osprey Military Journal II/3 (2000) 23-32.

6- Dunlop, "The British Isles," 15,18 \& 2 3-24; Lévi-Provençal, Histoire de l'Espagne Musulmane, vol. I, 354 \& vol. III, 342.

7- Dunlop, "Al-Bahr al-Muhit,"934; ibid., "The British Isles," 15-18 \& 22-24.

8- Lévi-Provençal, Histoire de l'Espagne Musulmane, vol. III, 297298; Dunlop, "The British Isles," 17-18; ibid., "Al-Bahr al-Muhit," 934.

9- D. M. Dunlop, "Al-Djaza'ir al-Khalida," in Encyclopedia of Islam, 2nd edit., vol. II (Leiden 1965) 522.

10- H. T. Norris, Saharan Myth and Saga (Oxford 1972) 4-5.

11- J. L. Yarrison, Force as an Instrument of Policy: European Military Incursions and Trade in the Maghrib, 1000-1355 (Ph D thesis, Princeton Univ. 1982) 118, 135 \& 227-228.

12- E. Lucie-Smith, Outcasts of the Sea: Pirates and Piracy (London \& New York 1978) 64-65.

13- J. D. Latham, "The Strategic Position and Defence of Ceuta in the Later Muslim Period," Islamic Quarterly XV (1971) 204.

14- B. Landström, The Quest for India (London 1964) 162 \& 187; G. Ferrand, Instructions Nautiques et Routiers Arabes et Portugais des $15^{e}$ et $16^{e}$ siècles, 3 vols. (Paris 1921-1928) passim.

15- S. D. Goiten, A Mediterranean Society: The Jewish Communities of the Ara World as Portrayed in the Documents of the Cairo Geniza, vol. I, Economic Foundations (Berkeley 1967) 305-306; D. A. Agius, "Maqrizi's Evidence for the Gurab: The Galley of the Mamluks," in U. Vermeuben \& J. M. F. Van Reeth (edits.), Law, Christianity and Modernism in Islamic Society (Leuven 1998) 195196; D. A. Agius, "Historical-Linguistic Reliability of Muqaddasi's Information on Types of Ships," in D. A. Agius \& I. R. Netton (eds.), International Medieval Research. Across Mediterranean Frontiers: Trade, Politics and Religion, 650-1450: 
Selected Proceedings of the International Medieval Congress, University of Leeds, 10-13 July 1995, 8-11 July 1996 (Turnhout 1997) 303-329; J.H. Pryor, Geography, technology and war: Studies in the maritime history of the Mediterranean 649-1571 (Cambridge 1988) 28 \& 32.

16- V. Christides, "The Transmission of Chinese Maritime Technology to the Arabs: The Single Stern Rudder, Greek Fire, Animal Transport Ships" (pre-publication draft of article); D.C. Nicolle, "Shipping in Islamic Art; Seventh through Sixteenth Century AD," American Neptune XLIX (1989) 168-197.

17- M. Rule \& J. Monaghan, A Gallo-Roman Trading Vessel from Guernsey: The Excavation and Recovery of a Third Century Shipwreck (Guernsey 1993) 125-131.

18- Nicolle, "Shipping in Islamic Art," 175-181.

19- V. Christides, "Naval Warfare in the Eastern Mediterranean $\left(6^{\text {th }}-\right.$ $14^{\text {th }}$ centuries): An Arabic Translation of Leo VI's 'Naumachica'," Graeco Arabica III (1984) 140-141; ibid., "Milaha: in the preIslamic and Medieval Arab Worlds," in Encyclopedia of Islam, $2^{\text {nd }}$ edit., vol. VIII (Leiden 1991) 44-45; ibid., "Navies: Islamic," in J. R. Strayer (ed.), Dictionary of the Middle Ages, vol. IX (New York 1992) 76; S. D. Goiten, "Glimpses from the Cairo Geniza on Naval Warfare in the Mediterranean and on the Mongol Invasion," in Studi Orientalistici in Onore di Giorgio Levi della Vida (Rome 1956) $395,397 \&$ note 1.

20- Al-Hassan, A.Y., \& D. R. Hill, Islamic Technology, an illustrated History (Cambridge 1986) 3 1-34 \& passim. 